\title{
Control of flea beetle, Phyllotreta nemorum L. (Coleoptera: Chrysomelidae) using locally available natural resources
}

\author{
Indra P Subedi* and Kamini Vaidya \\ Central Department of Zoology, Tribhuvan University, Kathmandu, Nepal \\ *Towhom correspondenceshould beaddressed.E-mail:indrasubedi@hotmail.com
}

\begin{abstract}
Aqueous extracts of six different plants (Acorus calamus, Ageratum conyzoides, Azadirachta indica, Duranta repens, Spilanthes acmella and Urtica dioca) and diluted animal urine (buffalo and cow) were tested for mortality rate of flea beetle (Phyllotreta nemorum) in the laboratory. Results were compared with the effects of commercial neem product (neem azal) on flea beetle mortality. The host plant taken for the study was radish (Rhaphanus sativus). Three concentrations of aqueous plant extracts $(1 \mathrm{~kg} / 5 \mathrm{l}, 1 \mathrm{~kg} / 10 \mathrm{l}$ and $1 \mathrm{~kg} / 20 \mathrm{I}$ of water), three concentrations of animal urine $(20 \%, 15 \%$ and $10 \%)$ and two concentrations of neem azal $(0.1 \%$ and $0.01 \%)$ were tested in three replications. Observations on the beetle mortality were made at $24 \mathrm{hrs}$ and thereafter on alternate days for a week (168 hrs). All tested concentrations of $\mathrm{S}$. acmella, buffalo urine and cow urine were effective in flea beetle control; $\mathrm{A}$. calamus, $\mathrm{A}$. indica and $\mathrm{U}$. dioca were significantly better in controlling flea beetle $(P<0.05)$, but only at the highest concentrations tested. The best treatments from in-vitro experimentation (the highest concentrations of $S$. acmella, buffalo urine and cow urine) were evaluated further in vivo. Results showed that all three treatments were effective in controlling the flea beetle $(P<0.05)$.
\end{abstract}

Key words: Cattle urine, marati, neem, neem azal, radish

Him J Sci 1(2): 111-114

URL: www.himjsci.com/issue2/fleabeetle
Received: 10 May 2003

Accepted after revision: 21 July 2003

\section{Introduction}

Theflea beetle(Phyllotreta nemorum) is a widespread and common pest of cruciferous plants. Frequently it is serious pest in seedbeds and on newly transplanted vegetables. The adults feed on the cotyledons and leaves of young plants; feeding produces a shot hole effect. Occasionally seedlings may be completely destroyed. Thelarvaelivein thesoil and feed upon theroots of thehost plants but do little damage.

Three species of flea beetles are reported from Nepal: P. cruciferae, P. nemorum and Monolepta signata (Vaidya 1995). Control of the flea beetle is a problem in many parts of the world. Fan and Huang (1991) included Phyllotreta species as serious pest in Taiwan. Various control measures, such as seed dressing with $\mathrm{BHC}$ or treatment with DDT, BHC or Derris dust, are in practice for thecontrol of theflea beetle. Turnoc and Turnbill (1995) reported the development of resistance by the cruciferous flea beetle ( $P$. cruciferae) towards insecticides including carbofuran, carbaryl, oxanyl, methamidofos and endosulfan. Fan and Huang(1991) also havenoted the development of resistance by theinsect. Along with resistance problems, there are many problems entailed in the application of chemical pesticides such as health hazards, environmental effects, adverse effects on non-target organisms, and destruction of natural enemies. Therefore, it is necessary to search for alternative methods to control the flea beetle in an ecofriendly manner. This paper reports on the use of natural agents such as plant- and animal-based products in controlling the flea beetle, P. nemorum.

\section{Materials and methods}

Experimentswerefirstcarried out in thelaboratory using test cages and then repeated in the field using those treatments found to be successful in the laboratory. The field trials were carried out in Pokhara Valley, Kaski district, Nepal, from March to June 1999. Testing was performed on adult flea beetles (P. nemorum). Insects were collected from the cruciferous plants (especially radish) in thestudyarea. Radish (Rhaphanussativus) was chosen for testing becauseitcan becultivated easilyand it allows effective assessment of flea beetles during the test. Transparent plastic bottles $7.5 \mathrm{~cm}$ high by $6 \mathrm{~cm}$ in diameter were used as test cages. The mouths of the bottles were covered with muslin to prevent the insects from escaping. Six pesticidal plants and 2 animal products were tested. Selection of the plants and animal products was based on information collected from local farmers; abundance and availability weretaken into consideration. The selected plantswere Acorus calamus (Bojho), Ageratum conyzoides (Ganmane ghans), Azadirachtaindica (Neem), Duranta repens(Nil kanda), Spilanthes acmella (Marati) and Urtica dioca (Stinging nettle). Buffalo urine and cow urine were the selected animal products. The natural resources were collected from the experimental site in Pokhara Valley. Neem azal (Azadirachtin), a commercial neem product provided by Trifolio-m-Gmbh, Germany, was the only formulated compound tested.

For the preparation of an aqueous extract, afixed amount of chopped plant parts was ground and soaked in water in polythene bags. The soaked materials were allowed to settle in the shade. After $48 \mathrm{hrs}$, the materials were squeezed and then filtered. The residuewasagain mixed with water and squeezed and filtered. This process was repeated three times. The filtrate was collected and diluted to make the required solution (Table 1).

Laboratory tests were carried out by spraying radish leaves with the various extracts, urine and neem azal, and placing them inside the experimental cages separately. Ten beetles were 
placed in each cagebottle. Themouths of the bottleswerecovered with muslin cloth for aeration and to prevent insect from escaping. The leaves inside thecage were replaced daily with leaves to which the same treatment had been applied at the beginning of the experiment. The experiment was continued for $168 \mathrm{hrs}$ of spray application.

For thefield experiment, threeblocks of equal size $4.5 \mathrm{~m}$ $\mathrm{x} 1 \mathrm{~m}$ ) wereprepared. Each block consisted of four plots. A distance of $50 \mathrm{~cm}$ was maintained between blocks and between plots. Each plot was of size $100 \mathrm{~cm}$ by $75 \mathrm{~cm}$. Twenty plants were planted in each plot. Treatments were randomly arranged.

In the laboratory, the treatment was applied using a syringe. The volume of spray solution per leaf was about 3 to $5 \mathrm{ml}$. In the field, a hand sprayer was used for spraying. The rate of treatment application was controlled by adjusting walking speed. The distance between the nozzles and the plant tips was about 40$50 \mathrm{~cm}$ during application. The applied spray volume corresponds

TABLE 1. Experimental materials and concentration of preparation used in the study

\begin{tabular}{llll}
\hline \multirow{2}{*}{ Experimental material } & \multicolumn{3}{c}{ Concentrations } \\
\cline { 2 - 4 } & $\mathbf{C}_{\mathbf{1}}$ & $\mathbf{C}_{\mathbf{2}}$ & $\mathbf{C}_{\mathbf{3}}$ \\
\hline $\begin{array}{l}\text { Fresh leaves of Ageratum } \\
\text { conyzoides, Azadirachta indica, } \\
\text { Urtica dioca }\end{array}$ & $1 \mathrm{Kg} / 5 \mathrm{I}$ & $1 \mathrm{Kg} / 10 \mathrm{I}$ & $1 \mathrm{Kg} / 20 \mathrm{I}$ \\
\hline $\begin{array}{l}\text { Fresh rhizome of Acorus } \\
\text { calamus }\end{array}$ & $1 \mathrm{Kg} / 5 \mathrm{I}$ & $1 \mathrm{Kg} / 10 \mathrm{I}$ & $1 \mathrm{Kg} / 20 \mathrm{I}$ \\
\hline $\begin{array}{l}\text { Fresh fruits of Duranta repens } \\
\text { Fresh flower heads of }\end{array}$ & $1 \mathrm{Kg} / 5 \mathrm{I}$ & $1 \mathrm{Kg} / 10 \mathrm{I}$ & $1 \mathrm{Kg} / 20 \mathrm{I}$ \\
\hline $\begin{array}{l}\text { Spilanthesacmella } \\
\text { Buffalo urine }\end{array}$ & $1 \mathrm{Kg} / 5 \mathrm{I}$ & $1 \mathrm{Kg} / 10 \mathrm{I}$ & $1 \mathrm{Kg} / 20 \mathrm{I}$ \\
\hline Cow urine & $20 \%$ & $15 \%$ & $10 \%$ \\
\hline Neem azal & $20 \%$ & $15 \%$ & $10 \%$ \\
\hline
\end{tabular}

to $500 \mathrm{ml} /$ plot. Thetime of application of test materialswas between $3 \mathrm{pm}$ to $4 \mathrm{pm}$. All theapplicationsweremade under natural weather conditions.

For assessment of mortality in the laboratory, three replicationswere used for each treatment. The effect of treatments on the flea beetlewas recorded at $24 \mathrm{hrs}, 72 \mathrm{hrs}, 120 \mathrm{hrs}$ and $168 \mathrm{hrs}$ of treatment application. The three most effective treatments, as assessed in the laboratory study, were used in the field tests. Five plants in each plot were selected randomly for observation. The number of live flea beetles on these five plants was noted before treatment and $24 \mathrm{hrs}$ after treatment application and then on alternate days for a period of one week.

The mortality coefficient (MC) value was estimated followingAbbott (1925):

$$
\begin{aligned}
& \text { MC }=[(\mathrm{T}-\mathrm{C}) /(100-\mathrm{C})] 100 \\
& \text { Where, } \quad \mathrm{T}=\text { Percentage mortality in control } \\
& \mathrm{C}=\text { Percentage mortality in treatment }
\end{aligned}
$$

In the laboratory, the percentage mortality of the flea beetle for the various treatments at varying concentrations $24 \mathrm{hrs}$ and $168 \mathrm{hrs}$ after treatment was analyzed by two-way ANOVA. In the field, thenumber of flea beetles per plant was used to estimate the mortality variance.

\section{Results}

\section{Laboratory experiment}

Variation in percentage mortality with time

In all treatments mortality occurred in the flea beetles. The percentage of mortality was higher in various treatments than in control and highest mortality occurred with Neem azal (Figure1, 2, 3). The mortality value gradually increased from the beginning of the treatment, and after $168 \mathrm{hrs}$, the values reached $76.7 \%$ for S. acmella, $73.3 \%$ for buffalo urine and $66.7 \%$ for cow urine at $C_{1}$ concentration. At $\mathrm{C}_{2}$ concentration, it was $70 \%, 66.7 \%$ and $60 \%$ for S. acmella, buffalo urineand cow urinerespectively. The percentage mortality data when analyzed for treatment effect showed a significant difference $(p \varangle 0.05)$ between treatment concentrations and among treatments.
TABLE 2. Mortality coefficient of flea beetle by treatment and concentration in laboratory

\begin{tabular}{|l|c|c|c|c|c|c|}
\hline \multicolumn{1}{|c|}{ Treatment } & \multicolumn{5}{c|}{ Mortality coefficient of flea beetle } \\
\hline & \multicolumn{5}{|c|}{$24 \mathrm{hrs}$ after treatment } & \multicolumn{3}{c|}{$168 \mathrm{hrs}$ after treatment } \\
\hline & $\begin{array}{c}1 \mathrm{Kg} / 5 \mathrm{I} \\
\left(\mathrm{C}_{1}\right)\end{array}$ & $\begin{array}{c}1 \mathrm{Kg} / 10 \mathrm{I} \\
\left(\mathrm{C}_{2}\right)\end{array}$ & $\begin{array}{c}1 \mathrm{Kg} / 20 \mathrm{I} \\
\left(\mathrm{C}_{3}\right)\end{array}$ & $\begin{array}{c}1 \mathrm{Kg} / 5 \mathrm{I} \\
\left(\mathrm{C}_{1}\right)\end{array}$ & $\begin{array}{c}1 \mathrm{Kg} / 10 \mathrm{I} \\
\left(\mathrm{C}_{2}\right)\end{array}$ & $\begin{array}{c}1 \mathrm{Kg} / 20 \mathrm{I} \\
\left(\mathrm{C}_{3}\right)\end{array}$ \\
\hline Acoruscal amus & 12.3 & 1.8 & 1.8 & 41.7 & 33.3 & 29.2 \\
\hline $\begin{array}{l}\text { Ageratum } \\
\text { conyzoides }\end{array}$ & 12.3 & 1.8 & 1.8 & 33.3 & 25 & 20.8 \\
\hline $\begin{array}{l}\text { Azadirachta } \\
\text { indica }\end{array}$ & 8.8 & 5.3 & 1.8 & 45.8 & 27.5 & 25 \\
\hline Duranta repens & 12.3 & 5.3 & 1.8 & 33.3 & 29.2 & 20.8 \\
\hline $\begin{array}{l}\text { Spilanthes } \\
\text { acmella }\end{array}$ & 19.3 & 8.8 & 15.8 & 70.8 & 62.5 & 45.8 \\
\hline Urtica dioca & 1.8 & 5.3 & 1.8 & 37.5 & 29.1 & 25 \\
\hline Buffalo urine & 22.8 & 19.3 & 12.3 & 66.7 & 58.3 & 50 \\
\hline Cow urine & 19.3 & 15.8 & 5.3 & 58.3 & 50 & 45.8 \\
\hline Neem azal & 57.9 & 5.3 & & 79.2 & 12.5 & \\
\hline Control & & $5 \%$ & & & $20 \%$ & \\
\hline
\end{tabular}

Mortality coefficient of flea beetle Mortality coefficients of flea beetles for each treatment at $24 \mathrm{hrs}$ and $168 \mathrm{hrs}$ after treatment application were calculated. The mortality coefficient increased with increase in concentration in all cases except in the case of S. acmella and U. dioca at $24 \mathrm{hrs}$ of treatment application.

Mortality coefficients for all treatments after $168 \mathrm{hrs}$ of treatments application were found to be greater than MC valuesat $24 \mathrm{hrs}$ of treatment application (Table 2). All concentrations of S. acmella, buffalo urine and cow urine showed significant effects. $\mathrm{C}_{1}$ concentration of $\mathrm{S}$. acmella, buffalo urine and cow urine showed MC values of $70.8,66.7$ and 58.3 respectively, which arecloseto the valuefor neem azal (79.2).

\section{Field experiment}

Percentage reduction in flea beetle population

At $24 \mathrm{hrs}$ of treatment application, the number of flea beetles per plant decreased 


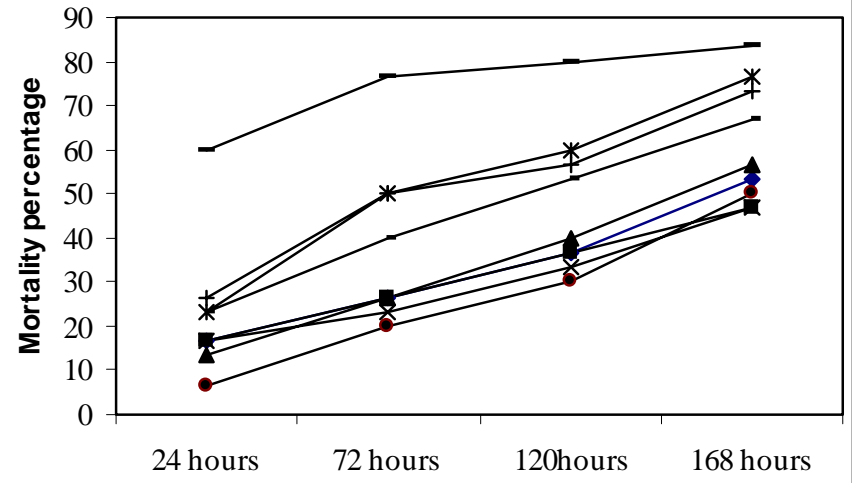

Period of observation

\begin{tabular}{|c|c|c|}
\hline $\begin{array}{l}\longrightarrow \text { A. calamus } \\
* \text { D. repens } \\
* \text { Buffalo urine }\end{array}$ & $\begin{array}{l}\rightarrow \text { A. conyzoides } \\
\rightarrow-S . \text { acmella } \\
\text { - Cow urine }\end{array}$ & \begin{tabular}{l}
$\longrightarrow$ A. indica \\
$\because-U$. dioca \\
\hdashline Neem azal
\end{tabular} \\
\hline
\end{tabular}

FIGURE 1. Percentage mortality of flea beetle for different treatments with respect to duration of treatment at $C_{1}$ concentration $(1 \mathrm{~kg} / 5 \mathrm{l})$ in laboratory

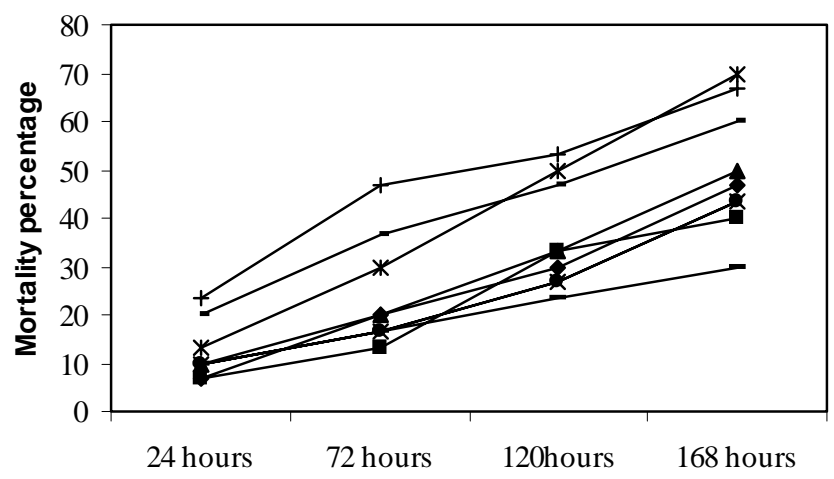

Period of observation

\begin{tabular}{|c|c|c|}
\hline $\begin{array}{l}\multimap \text { A. calamus } \\
* \text { D. repens }\end{array}$ & $\begin{array}{l}\rightarrow \text { - A. conyzoides } \\
\rightarrow-S \text {. acmella }\end{array}$ & $\begin{array}{l}\longrightarrow \text { A. indica } \\
\longrightarrow-U \text {. dioca }\end{array}$ \\
\hline
\end{tabular}

FIGURE 2. Percentage mortality of flea beetle for different treatments with respect to duration of treatment at $C_{2}$ concentration $(1 \mathrm{~kg} / 10 \mathrm{I})$ in laboratory
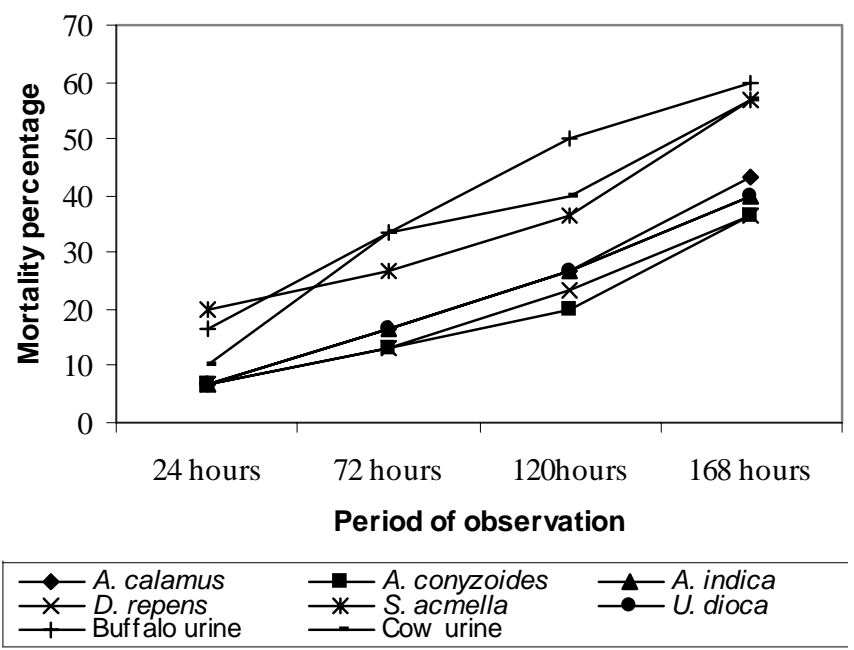

FIGURE 3. Percentage mortality of flea beetle for different treatments with respect to duration of treatment at $C_{3}$ concentration $(1 \mathrm{~kg} / 20 \mathrm{I})$ in laboratory by $76 \%$ with cow urine, $74.5 \%$ with S. acmella and $55.7 \%$ with buffalo urine whereas in the control plot the value corresponds to 10.1\% (Figure 4). The highest reduction in flea beetle population was recorded in plots treated with cow urine. One week after treatment, therewasasignificantreduction in flea beetlepopulations (buffalo urine $75.4 \%$, cow urine $75 \%$ and S. acmella $70.9 \%$ ), whilein the control plot thenumber of flea beetle per plant remained more or less stable throughout the study period (Figure4).

Variation in population per plant with respect to time

In the field, the population of flea beetles was greatly reduced in all treated plots compared to those in control plots. In the control plot, there was a slight fluctuation in the number of live flea beetle per plant. Flea beetle population per plant at theend of experiment was found to be the least on plants treated with cow urine (1.8 insects/plant). Buffalo urine (2.0) and S. acmella (2.1) were the second and third mosteffectivetreatments. However, in thecontrol plot, therewasonly aslight changein populations, from an average of 9.2 before treatment to 8.9 one week after treatment (Figure5). The differences among the treatments werestatisticallysignificant

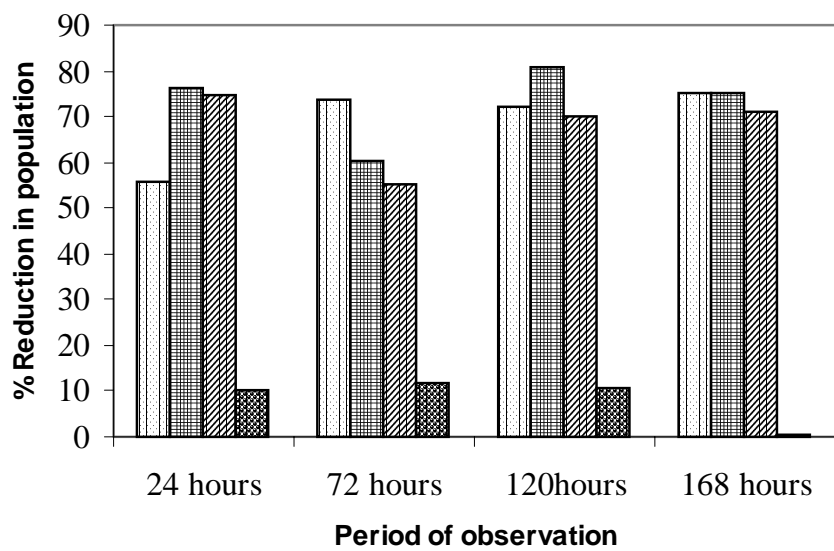

$\square$ Buffalo urine 国 Cow urine S. acmella 圆 control

FIGURE 4. Percentage reduction in flea beetle population after treatment at $\mathrm{C}_{1}$ concentration $(1 \mathrm{~kg} / 5 \mathrm{I})$ in field

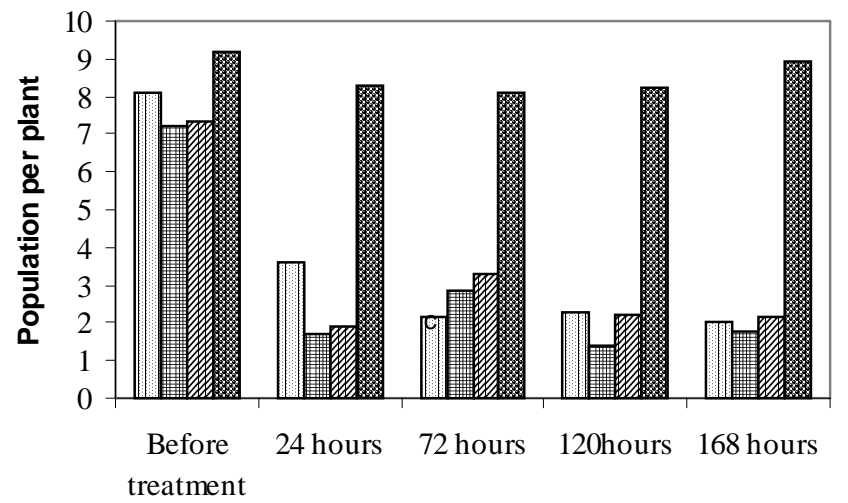

Period of observation

Buffalo urine 国 Cow urine S. acmella 娄 control

FIGURE 5. Flea beetle population per plant with respect to duration of treatment at $C_{1}$ concentration $(1 \mathrm{~kg} / 5 \mathrm{I})$ in field 
$(p \varangle 0.05)$. However, treatments werenotsignificant at $1 \%$ level at 24 hrs of treatment application. The effect was highly significant $(p \varangle 0.01)$ after $168 \mathrm{hrs}$ of treatment application.

\section{Discussion}

The study shows that all the tested natural resources possess pesticidal properties to somedegreeor other. A. calamus,A. indica, S. acmella, U. dioca, buffalo urine and cow urine are proved effective agents for flea beetle control; the effect of $A$. conyzoides and D. repenswas not significant.

All tested concentrations of S. acmel la showed significant results. Kadir et al. (1989) also showed that extracts of S. acmella were toxic against adult American cockroach (Periplaneta americana). The pesticidal property of $\mathrm{S}$. acmella is due to its active component Spilanthol (Kadir et al. 1989). The N-isobutyl amides from flower buds of $\mathrm{S}$. acmella were effective against Aedes aegypti larvae and Heli coverpa zea neonates at 12.5 and $250 \mu \mathrm{g} / \mathrm{ml}$ concentration respectively (Ramsewak et al. 1999).

Regmi and Karna (1998) haveshown that A. calamusand A. indica have pesticidal value. Powdered rootstock of $A$. calamus has been reported effectiveasan insecticide, repellent and contact poison, and A. indica as a plant of multifarious pesticidal values (Regmi and Karna 1998). Joshi and Paneru (1999) described A. calamus, A. conyzoides, $A$. indica and $U$. dioca as plants with potent insecticidal properties and A. indica is effective against the flea beetle. Palaniswamy and Wise (1994) reported that neem-based products are effective with high mortality or repellency against the crucifer flea beetle (P. cruciferae). The pesticidal property of $A$. indica is due to the active principle, the limnoid azadirachtin. Azadirachtin is the most potent natural insect antifeedant, which suppresses insect feeding at concentration of less than 1 ppm (Ishman etal. 1991).

Cow urine and buffalo urine both showed significant resultsatall concentrations. Cow urineistraditionally widely used in Nepal for variouspurposes, includingreligious, ritual and medical applications, and insect control. According to Vaidya (1993), cow urine is the most effective solution for the control of Lipaphis erysimi, Myzus persicaeand Dorylusorientalis. Budhathoki (1992) reported that diluted cow urine applied on broad leaf mustard significantly reduces powdery mildew. Farmers use cow urine in various concentrations (1:2 to 1:5) as curative plant protection measures against aphids of cowpea and bean and late blight of potato and tomato (Gyawali et al. 1994).
In the laboratory, no tested natural resources showed significant results at $24 \mathrm{hrs}$ of treatment application. However, in the field, there was marked population reduction at $24 \mathrm{hrs}$ of treatment application. It may be due to the repellent effect of different treatments. The effects persist up to one week and there wasremarkablepopulation reduction in the field even $168 \mathrm{hrs}$ after treatmentapplication.

\section{References}

AbbottWS. 1925. Amethod of computingtheeffectiveness of insecticides.J Econ Entomo 18: $265-7$

Budhathoki K. 1992. Vegetablefarmingthrough indigenoustechnology. Lumle(Kaski): Lumle Regional Agricultural Research Centre. Seminar paper no 92/ 15

Fan KY and IJ Huang. 1991. Occurrenceand control of major insect pestson vegetables in Taiwan. Chin J Entomol Spec Publ Ola 4: 1-13

Gyawali S, RB Thapa and P Amatya. 1994. Assessment of indigenous knowledge in plant protection for possibleintegration into intregated pestmanagement. In NeupaneFP and M Kharel (eds), IAAS research reports. Rampur: IAAS. p 107-27

Ishman MB, O Koul, JT Arnason,J Stewart and GSSalloum. 1989. Developinganeem based insecticidefor Canada. Mem Entomol SocCan 159: 39-47

Joshi SLand RB Paneru. 1999. Botanicalsagainstinsectpests of agricultural importance in Nepal. Paper presented on "Regional training program in chemistry of natural productsand related fields"; 1999May 18-28; Kathmandu, Nepal. Kathmandu: Central Department of Chemistry, Tribhuvan University

KadirHA, MBZakaria,AAKechil and MSAzirum. 1989. Toxicityand electrophysiological effects of Spilanthesacmella Murr. extractson Periplaneta americana. PesticSa 25(4): 329-36

Palaniswamy Pand I Wise. 1994. Effects of neem based productson number and feeding activity of crucifer flea beetle, Phyllotreta cruciferae(Goeze) on canola.J Agric Entomol 11(1): 49-60

RamsewakRS, AJ Erickson and MG Nair. 1999. BioactiveN-isobutylamidesfrom flower buds of Spilanthesacmella. Phytochemistry(Oxford) 51(6): 729-32

Regmi PP and PP Karna. 1988. Weedsand other plants of pesticidal valuesin Nepal. In: Proceedingsof 1stNational Conferenceon Scienceand Technology; 1988Apr 24 29; Kathmandu, Nepal. Kathmandu: RONAST. p 161-73

Turnoc W] and SA Turnbill. 1995. The development of resistance to insecticides by cruciferousflea beetle, Phyllotreta cruciferae Can Entomol 126(6): 1369-75

Vaidya K. 1993. Agricultural pest management using animal and plant products. Kathmandu:Tribhuvan University. $x i+135 p$

Vaidya K. 1995. Organic pest management [project report]. Kathmandu: Tribhuvan University. AAA GATE/TU. $300 p$

\section{Acknowledgements}

Wewould liketo express our sinceregratitudeto Tej K Shrestha, Suresh B Karki and Vasanta K Thapa (Central Department of Zoology, TU) for their encouragement, guidance and assistance, especially in providing necessary laboratory facilities. Wearethankful to SR Ghimire(LumleAgricultureResearch Centre) for revising thispaper, and to Trifolio-m Gmbh, Germany for providing uswith Azadirachtin. 